\title{
The impact of patents on the development of genome-based clinical diagnostics: an analysis of case studies
}

\author{
Brandon L. Pierce, PhD ${ }^{1,2}$, Christopher S. Carlson, PhD ${ }^{2,3}$, Patricia C. Kuszler, JD, MD ${ }^{1,4}$, \\ Janet L. Stanford, $P h D^{2,3}$, and Melissa A. Austin, $P h D^{1,2,3}$
}

\begin{abstract}
Purpose: Fragmented ownership of diagnostic gene patents has the potential to create an "anticommons" in the area of genomic diagnostics, making it difficult and expensive to assemble the patent rights necessary to develop a panel of genetic tests. The objectives of this study were to identify US patents that protect existing panels of genetic tests, describe how (or if) test providers acquired rights to these patents, and determine if fragmented patent ownership has inhibited the commercialization of these panels. Methods: As case studies, we selected four clinical applications of genetic testing (cystic fibrosis, maturityonset diabetes of the young, long QT syndrome, and hereditary breast cancer) that use tests protected by $\geq 3$ US patents. We summarized publically available information on relevant patents, test providers, licenses, and litigation. Results: For each case study, all tests of major genes/mutations were patented, and at least one party held the collective rights to conduct all relevant tests, often as a result of licensing agreements. Conclusions: We did not find evidence that fragmentation of patent rights has inhibited commercialization of genetic testing services. However, as knowledge of genetic susceptibility increases, it will be important to consider the potential consequences of fragmented ownership of diagnostic gene patents. Genet Med 2009:11(3):202-209.
\end{abstract}

Key Words: patent, intellectual property, genetic testing, licensing, anticommons

$P$ atents protecting the rights to conduct specific genetic tests (i.e., "diagnostic gene patents") have been a source of debate for several reasons, including their possible negative impacts on the quality, cost, and availability of clinical genetic services. ${ }^{1,2}$ It has also been argued that fragmented ownership of these patents can create an "anticommons"3 or a "patent thicket," making it difficult and expensive for a single party to assemble the patent rights necessary to develop a panel of genetic tests for clinical purposes. ${ }^{4}$ In such a situation, any owner of a diagnostic gene patent that is critical to a specific panel of tests will be able to prevent the commercialization of any panel that includes the patented test. The owner could seek a court injunction ordering the commercializer to stop infringing the patented invention

From the ${ }^{1}$ Institute for Public Health Genetics, University of Washington, Seattle; ${ }^{2}$ Epidemiology Program, Fred Hutchinson Cancer Research Center, Seattle, Washington; ${ }^{3}$ Department of Epidemiology; and ${ }^{4}$ School of Law, University of Washington, Seattle, Washington.

Brandon Pierce, $\mathrm{PhD}$, University of Chicago, 5841 South Maryland Avenue, MC 2007, Chicago, IL 60637. E-mail: brandonpierce@uchicago.edu.

Disclosure: The authors declare no conflict of interest.

Supplemental digital content is available for this article. Direct URL citations appear in the printed text and are provided in the HTML and PDF versions of this article on the journal's Web site (www.geneticsinmedicine.org).

Submitted for publication July 11, 2008

Accepted for publication November 7, 2008.

DOI: $10.1097 /$ GIM.0b013e3181948faf (and/or seek monetary damages) or demand that the commercializer take a license to the patent(s) under the threat of these legal actions. With the development of oligonucleotide arrays and other technologies capable of conducting many genetic tests at once (i.e., "genomic diagnostics") and the diverse applications of such technologies (e.g., diagnostics, susceptibility testing, tumor typing, pathogen detection), the potential for an anticommons in the area of genomic diagnostics may be increasing. ${ }^{4}$

Further increasing this concern is the rapid rate at which common disease susceptibility variants are being identified by researchers conducting genome-wide association (GWA) studies. ${ }^{5}$ GWA methods have the potential to identify many more common variants that influence risk for complex diseases and drug response, and although these variants usually have modest effects, test of these variants may have clinical utility when information from several tests are combined. Considering the widespread adoption of GWA methodology, ${ }^{6}$ it is possible that variants related to the same clinical application will be discovered and patented by different parties, resulting in fragmented patent ownership.

It is likely still too early to assess potential anticommons effects of diagnostic gene patents resulting from GWA studies because discoveries are still emerging and patents take several years to be issued. However, similar problems may already exist for companies that provide genetic testing for relatively rare hereditary conditions characterized by genetic heterogeneity (i.e., caused by one of many mutations, potentially in several different genes). The objective of this study was to identify the patents that protect existing genetic tests and describe how (or if) test providers acquired the rights to these patents. Through this process, we aim to determine if the variants relevant to specific tests are/were owned by multiple parties and if there is any evidence that fragmented ownership of patent rights has inhibited the development of genetic testing products or services. In addition, we hope that a description of the assignment and licensing of these patents will inform future policy decisions related to genomic diagnostics.

\section{MATERIALS AND METHODS}

For this analysis, a case study was defined as a clinical application of genetic testing. To be included in this analysis, a case study was required to be a clinical application that used genetic tests protected by at least three US patents. We identified potential case studies using searches of genetics review articles, websites of companies conducting genetic testing, and personal communication with researchers and clinicians. For each selected case study, relevant genetic risk factors were identified using scientific review articles. Once the genetic risk factors were established, all relevant diagnostic gene patents were identified through gene-specific and disease-specific searches of the database of issued patents at the United States 
Patent and Trademark Office's (USPTO) website. For example, for cystic fibrosis (CF) testing, all titles and abstracts in the USPTO patent database were searched for the terms "cystic fibrosis" (which also captures "cystic fibrosis transmembrane conductance regulator" $[C F T R]$, the gene that is mutated in individuals with $\mathrm{CF}$ ) and for "CFTR." For each patent identified, we then used the patent title, abstract, and claims to determine if the patent protects a genetic test of human DNA. Claims are expressions within a patent that define the boundaries of patent protection. A diagnostic gene patent typically has claims that are methods of preparing or administering a test and/or claims that are "compositions of matter," the physical tools or substrates used in the testing process (i.e., specific DNA sequences, primers, probes, kits). For each patent, we deemed relevant to the study, the patent number, an assignee, and a summary of the claims were catalogued. All searches were conducted before August 21, 2008.

We summarized several characteristics of each case study: (i) the number of relevant patents and corresponding assignees, (ii) the number of test providers, (iii) the types of licenses issued, (iv) the presence or absence of patent litigation, and (v) the patent rights held by the current providers. For each case study, all current US test providers were identified using the Gene Tests website (www.genetests.org). Various sources were used to obtain information related to the license agreements that facilitated the development of each product; these sources included company press releases, financial statements, diagnostics companies' websites, university technology transfer websites, and personal communication with university technology transfer offices. Because press releases may exaggerate claims of license exclusivity, these must be interpreted with caution.

\section{RESULTS}

On the basis of the criteria described above, four eligible case studies were identified. These clinical applications of genetic testing correspond to four diseases: $\mathrm{CF}$, maturity-onset diabetes of the young (MODY), long QT Syndrome (LQTS), and hereditary breast cancer (BRCA).

\section{Cystic fibrosis}

$\mathrm{CF}$ is a complex multisystem disease characterized by chronic pulmonary disease and gastrointestinal abnormalities. ${ }^{7}$ Diagnosis typically occurs in the first 6-8 months of life or, in some states, as a result of newborn screening. ${ }^{7} \mathrm{CF}$ is caused by mutations in the CFTR gene. Over 1000 mutations in CFTR have been identified, but the DeltaF508 mutation accounts for $\sim 72 \%$ of CFTR mutations found in clinically confirmed CF patients of European descent in the United States. ${ }^{8}$ The National Institutes of Health Consensus Development Conference Statement on Genetic Testing for $\mathrm{CF}$ recommends carrier screening for adults with a family history of $\mathrm{CF}$, partners of people with $\mathrm{CF}$, couples currently planning a pregnancy, and couples seeking prenatal care. ${ }^{7}$ The American College of Medical Genetics (ACMG) and the American College of Obstetrics and Gynecology (ACOG) have recommended 23 specific mutations for inclusion in screening panels. ${ }^{8,9}$

Key patents on genetic tests of CFTR are owned by three different assignee groups: (1) the Hospital for Sick Children (HSC) and University of Michigan (Michigan) (joint ownership); (2) Johns Hopkins University (Hopkins); and (3) HSC as a sole assignee (Table 1 and Table, Supplemental Digital Content 1, http://links.lww.com/A707). HSC and Michigan jointly filed for the first CFTR patent on methods and tools for detection of the DeltaF508 mutation (patent 5,776,677) and were subsequently assigned several additional patents related to
Table 1 Summary of patents related to testing of the cystic fibrosis (CF) gene

\begin{tabular}{ccc}
\hline $\begin{array}{c}\text { Number of } \\
\text { patents }\end{array}$ & \multicolumn{1}{c}{ Summary of claims } & \multicolumn{1}{c}{ Assignee } \\
\hline 5 & $\begin{array}{c}\text { DNA, tools, and methods for } \\
\text { detecting Delta F508 } \\
\text { mutation, antibodies, } \\
\text { polypeptides }\end{array}$ & $\begin{array}{c}\text { HSC and University of } \\
\text { Michigan }\end{array}$ \\
& $\begin{array}{c}\text { Probes, methods for } \\
\text { detection of } 4 \text { mutations }\end{array}$ & $\begin{array}{c}\text { Johns Hopkins } \\
\text { University }\end{array}$ \\
& $\begin{array}{c}\text { DNA, tools, methods for } \\
\text { detecting 20 mutations }\end{array}$ & HSC \\
\hline HSC, Hospital for sick children. & \\
\hline
\end{tabular}

DeltaF508. Hopkins was issued a patent relating to the detecting four specific CFTR mutations (patent 5,407,796), and HSC was assigned patents related to the detection of 20 additional CFTR mutations (patent 5,981,178). The majority of the $>1000$ known CFTR mutations are rare and not explicitly claimed in any US patent. Companies such as Third Wave Technologies, Inc. have been issued patents related to specific methods and kits for detecting CFTR mutations (e.g., patent 7,312,033), but such patents are not critical to traditional CFTR testing technologies.

Over 60 laboratories in the United States currently offer genetic testing services for the CFTR gene, and these services range from analysis of targeted mutations to complete sequencing of all CFTR coding regions. Targeted mutation analyses often involve screening for, at minimum, the 23 mutations recommended by the ACMG and the ACOG. Genetics Laboratories at academic centers such as Baylor ${ }^{10}$ and Emory ${ }^{11}$ offer CFTR sequencing for $\$ 1800$ and $\$ 2000$, respectively, and targeted mutation analysis for $\$ 200$ and $\$ 316$, respectively. Ambry Genetics offers an analysis of only the DeltaF508 mutation (508 FIRST $^{\mathrm{TM}}$; $\$ 84$ or $\$ 59$ institutional rate) and a comprehensive CFTR analysis (CF AMPLIFIED ${ }^{\text {TM}}$; $\$ 3358$ or $\$ 1595$ institutional) for patients not homozygous for DeltaF508 (unpublished data). Genzyme's CFplus ${ }^{\mathrm{TM}}$ test detects 97 mutations (\$463), and their CFTR sequencing service includes an analysis of all 27 exons, splice sites, and clinically-relevant intronic regions (\$2400) (unpublished data). Luminex’s Molecular Diagnostics division offers the $\mathrm{xTag}^{\mathrm{TM}} \mathrm{CF}$ Kit, which screens for the 23 mutations and four polymorphisms recommended by the ACMG and the ACOG for 16 additional mutations. ${ }^{12}$ This test has been cleared by the US Food and Drug Administration as an in vitro diagnostic. ${ }^{12}$

The Office of Technology Transfer at Michigan, which oversees the US licensing activities of the patents assigned to Michigan and HSC, has granted many nonexclusive licenses for their patents relating to $\mathrm{CF}$ testing (including the Delta508 mutation) to companies in both the US and abroad. ${ }^{13}$ Michigan and HSC share the royalties from these licenses. ${ }^{13}$ Hopkins is also licensing its $\mathrm{CF}$ patent nonexclusively. ${ }^{14}$ Because licenses to all relevant patent rights seem to be available to any interested party, CF testing is offered by multiple laboratories and companies manufacturing in vitro diagnostics.

\section{Maturity-onset diabetes of the young}

MODY refers to a group of conditions characterized by familial hyperglycemia developing in childhood or young adulthood, insulin secretion defects, and autosomal dominant inheritance pattern. ${ }^{15}$ MODY accounts for an estimated 5\% of dia- 
betes mellitus in the United States ${ }^{16}$ and genetic predisposition to the disease is partially attributable to mutations in six known genes: HNF1A (MODY1), GCK (MODY2), HNF4A (MODY3 or TCF1), PDX1 (MODY4 or IPF1), HNF1B (MODY5 or TCF2), and neuroDl (MODY6). Mutations in GCK and HNF4A are the most common MODY mutations, whereas $16-45 \%$ of MODY cases are of unknown etiology. ${ }^{17}$ Testing for MODY mutations can confirm a diagnosis, define a disease subtype, or provide predictive information about disease, guiding physicians' advice regarding treatment, and prognosis. ${ }^{18}$

Athena Diagnostics (Athena) and Ambry Genetics (Ambry) are the only US providers of MODY testing. Athena's Monogenic Diabetes Evaluation detects mutations in five of the six known MODY genes (MODY1-MODY5). This service entails full sequencing of the coding sequences for all five genes and costs $\$ 2090$ (unpublished data). The results are interpreted by Athena, and a report is sent to the patient's physician. Ambry offers sequential sequencing of MODY genes in order of decreasing mutation frequency. $H N F 4 A$ is sequenced, then $G C K$, followed by $H N F 1 A$. Ambry's analysis of all three genes (if necessary) costs \$3986 (institution price: \$1700) (unpublished data). Sequencing of $P D X 1$ and $H N F 1 B$ is also available from Ambry.

Methods for detecting mutations in MODY1-MODY5 are protected by at least five US patents (Table 2 and Table, Supplemental Digital Content 2, http://links.lww.com/A708). The rights to test for mutations in four of the five genes were assigned to Arch Development Corp. (patents 5,541,060 and $6,187,533$ ), a not-for-profit affiliate of the University of Chicago that handled the university's intellectual property and technology commercialization when the patents were filed. ${ }^{19}$ Rights to test for mutations in the remaining gene, $P D X 1$, were assigned to the General Hospital Corporation (GHC) (patent 6,274,310). Additional patents assigned to Samsung Electronics claim tools and methods for multiplex PCR of $H N F 1 A$, but these patents do not seem to be critical to the current testing technologies (i.e., Athena does not report them to be protecting its test). To our knowledge, there are no US patents related to tests of NEUROD1 (MODY6), a gene accounting for a rare MODY subtype (i.e., mutations observed in only two families ${ }^{20}$ ).

The University of Chicago has issued Correlagen Diagnostics Inc. a worldwide exclusive license to the patents related to diagnosis based on $H N F 1 A, H N F 4 A$, and $H N F 1 B .{ }^{21}$ Correlagen then issued a sublicense to Athena, which currently offers MODY testing. ${ }^{22}$ Athena's website indicates that its test is also covered by GHCs patent, suggesting that Athena has obtained rights to this patent as well. ${ }^{23}$ Ambry offers a similar MODY genetic testing service, ${ }^{24}$ although we were unable to determine how Ambry obtained the necessary rights to perform the test. The rights have not been licensed to Ambry from Correlagen (unpublished data) suggesting that Correlagen's sublicense to

Table 2 Summary of patents on maturity-onset diabetes of the young (MODY) genes

\begin{tabular}{ccc}
$\begin{array}{l}\text { Number of } \\
\text { patents }\end{array}$ & Summary of claims & Assignee \\
\hline 2 & $\begin{array}{c}\text { Methods for mutational analysis } \\
\text { of } H N F 1 A \text { (TCF1), } H N F 4 A,\end{array}$ & University of Chicago \\
& $H N F 1 B$ (TCF2) and GCK & \\
& Methods for detecting mutations & GHC \\
1 & in PDX1 (IPF1) & \\
\hline GHC, General Hospital Corporation. \\
\hline
\end{tabular}

Athena is exclusive (If Athena has obtained the right to grant sublicenses, then it is theoretically possible that the rights to conduct MODY testing were sublicensed from Athena to Ambry; however, no information is currently available to support or refute this possibility). Regardless, the rights to all relevant MODY tests have been licensed to at least one current test provider (i.e., Athena).

\section{Long QT Syndrome and related syndromes}

There are eight genes known to harbor mutations associated with LQTS, ${ }^{25}$ a condition affecting the electrical system of the heart that results in a predisposition to cardiac arrhythmias and sudden death in young individuals. ${ }^{26}$ LQTS can be inherited in an autosomal dominant or recessive pattern depending on the nature of the mutation. ${ }^{25} \mathrm{KCNQ1}$ (LQT1), KCNH2 (LQT2), SCN5A (LQT3), KCNE1 (LQT5), and KCNE2 (LQT6) are considered to be the major LQT genes, whereas ANK2 (LQT4), KCNJ2 (LQT7), and CACNA1C (LQT8) harbor a small percentage of LQTS mutations. ${ }^{25}$ Genetic testing for LQTS is considered to be of clinical value because mutation carriers who lack QT interval prolongation $(\sim 40 \%)^{26}$ still have a $10 \%$ risk of a cardiac event by age 40 if untreated. ${ }^{27}$ Algorithms have been developed that perform risk stratification in an allele-specific manner and are available for patient management and treatment. ${ }^{27,28}$

At least 17 US patents claim methods, sequences, and/or tools related to mutation detection in the five major LQTS genes and one minor LQTS gene (KCNJ2, which harbors mutations in $\sim 0.05 \%$ of individuals with the LQTS phenotype ${ }^{25}$ ) (Table 3 and Table, Supplemental Digital Content 3, http://links.lww.com/A709). The University of Utah Research Foundation (UURF) is listed as an assignee on each of these patents, with Genzyme Corp. and Yale University as coassignees on patents related to LQT1 and LQT6, respectively. To our knowledge, there are no issued patents pertaining to the two minor LQTS genes, $A N K 2$ or $C A C N A 1 C$, which harbor mutations in approximately 1.1 and $0.006 \%$ of individuals with the LQTS phenotype, respectively. ${ }^{25}$ However, there is a submitted patent application (still under review) claiming $C A C N A 1 C$ nucleic acids and peptides and methods for determining risk of sudden cardiac death (Applications 20080118438)

PGxHealth, a division of Clinical Data, Inc., is currently the only provider of mutational analysis of LQTS genes in the United States. Blood of individuals with suspected LQTS, Brugada syndrome (a related syndrome that can be caused by mutations in $S C N 5 A^{25}$ ), or family members of diagnosed individuals, is sent to PGxHealth by a physician. ${ }^{29}$ PGxHealth's FAMILION® test can be ordered in one of three configurations: (1) comprehensive sequencing of all five major LQTS genes $(\$ 5,400)$, (2) analysis of SCN5A only (for Brugada Syndrome; \$2,700), or (3) a familyspecific analysis of mutations already identified in other family members (\$900). ${ }^{30,31}$ Mutations found are classified into three categories based on comparisons with reference sequence and PGxHealth's Cardiac Ion Channel Variant Database: deleterious/ probably deleterious, possibly deleterious, and not expected to be deleterious. ${ }^{31}$ PGxHealth reports that their test will detect mutations in $50-75 \%$ of LQTS cases and $15-20 \%$ of the cases of Brugada Syndrome. ${ }^{29,31}$

LQTS testing was originally offered by Genaissance Pharmaceuticals, Inc. (Genaissance). Genaissance's annual SEC statement for 2004 (Form 10-K) indicates that the UURF and Yale University extended Genaissance certain rights related to five cardiac ion channel genes known to harbor mutations associated with LQTS. ${ }^{32}$ Form $10-\mathrm{K}$ also indicates that these patents were originally licensed to DNA Sciences, a company 
Table 3 Summary of patents related to testing long QT (LQT) syndrome genes

\begin{tabular}{lclc}
\hline Gene & Number of patents & \multicolumn{1}{c}{ Summary of claims } & Assignees \\
\hline KCNQ1 (LQT1) & 4 & $\begin{array}{l}\text { DNA, methods for detecting 17 mutations; tools, methods for } \\
\text { mutation analysis } \\
\text { DNA, probes, methods of diagnosis, methods for detecting } 6 \\
\text { mutations }\end{array}$ & UURF and Genzyme, Corp. \\
KCNH2 (LQT2) & 2 & DNA, probes, methods for 68 mutations \\
SCN5A (LQT3) & 2 & DNA, probes, methods for 8 mutations & UURF \\
$K C N E$ 1 (LQT5) & 4 & $\begin{array}{l}\text { Isolated DNAs comprising } 7 \text { mutations; methods for } \\
\text { detecting one mutation }\end{array}$ & UURF \\
$K C N E 2$ (LQT6) & 1 & DNA, RNA, cells, vectors for 4 mutations & UURF and Yale University \\
$K C N 52$ (MODY7) & 1 & Methods for detecting 7 mutations & UURF \\
\hline UURF, University of Utah Research Foundation. & &
\end{tabular}

that was later acquired by Genaissance in May of 2003. ${ }^{32}$ Press releases from DNA Sciences indicate that these licenses were exclusive. ${ }^{33}$

In 2002, before being acquired by Genaissance, DNA Sciences was involved in a patent dispute with Genedx, a company allegedly infringing DNA Sciences's exclusive rights to patents related to commercial genetic testing of LQTS genes (DNA Sciences, Inc. v. GeneDx, Inc., Civ. No. 02-5578 [N.D. Cal.]). The dispute was settled out of court soon after the complaint was filed, and the case was dismissed in early $2003 .{ }^{34}$ Genedx agreed to abandon their LQTS testing services, eliminating the availability of commercial LQTS testing for approximately 2 years, ${ }^{35}$ until Genaissnace began offering the test in $2004 .{ }^{34}$ Genaissance was acquired by Clinical Data, Inc. (i.e., PGxHealth) in October of 2005. As a result, PGxHealth owns all necessary patent rights to conduct LQTS testing and is the sole provider of LQTS testing in the United States.

\section{Hereditary breast cancer}

Deleterious or clinically significant mutations in the $B R C A 1$ and $B R C A 2$ genes are strongly associated with risk for breast and ovarian cancer, resulting in a lifetime breast cancer risk of $60-85 \% .{ }^{36}$ Guidelines recommend testing when an individual's personal or family history suggests an inherited susceptibility. ${ }^{37,38}$ For at risk individuals, there are many available tools for assessing the risk associated with a mutation, and based on this risk, experts may recommend options such as earlier and more frequent screening, chemoprevention, and prophylactic surgery. ${ }^{36}$

There are at least 17 patents that claim methods, sequences, and/or tools related to genetic tests of $B R C A 1$, and these have been assigned to at least seven unique assignee groups. The earliest patent on BRCAl was filed by the Regents of the University of California, but the patents most critical to mutation detection were filed by OncorMed, Inc. (OncorMed) (later acquired by Gene Logic, Inc.) and Myriad Genetics, Inc. (Myriad) (with various coassignees) (Table 4 and Table, Supplemental Digital Content 4, http://links.lww.com/A710). OncorMed, UURF, Myriad, and Rijksuniverseteit Te Leiden were later assigned additional patents relating to the detection of novel mutations not specifically claimed in previous patents. Companies such as Visible Genetics, Inc. and Hybritech, Inc. were assigned patents on novel methods for mutation detection,
Table 4 Summary of patents related hereditary breast cancer $(B R C A)$ genes

\begin{tabular}{|c|c|c|}
\hline $\begin{array}{l}\text { Number of } \\
\text { patents }\end{array}$ & Summary of claims & Assignee \\
\hline & $B R C A 1$ & \\
\hline 3 & $\begin{array}{l}\text { DNA, proteins, screening methods } \\
\text { for } 12 \text { alleles }\end{array}$ & $\begin{array}{l}\text { University of } \\
\text { California }\end{array}$ \\
\hline 3 & $\begin{array}{l}\text { DNA, proteins, tools, and methods } \\
\text { for detecting specific mutations } \\
\text { and mutation analysis }\end{array}$ & $\begin{array}{l}\text { Myriad, UURF, } \\
\text { NIH }\end{array}$ \\
\hline 2 & $\begin{array}{l}\text { DNAs, probes, methods for many } \\
\text { alterations }\end{array}$ & Myriad, CHUQ, CI \\
\hline 6 & $\begin{array}{l}\text { Consensus sequence, } 7 \text { SNPs, tools, } \\
\text { methods for specific mutations } \\
\text { and determining haplotypes }\end{array}$ & OncorMed \\
\hline 1 & $\begin{array}{l}\text { Isolated gene with Alu-related } \\
\text { deletion }\end{array}$ & UURF \\
\hline 1 & $\begin{array}{l}\text { Probes, methods for detecting } \\
\text { specific deletions }\end{array}$ & U Leiden \\
\hline 1 & DNA comprising large deletion & Myriad \\
\hline & $B R C A 2$ & \\
\hline 2 & $\begin{array}{l}\text { DNA, tools and methods for } \\
\text { related to } 39 \text { mutations; } \\
\text { Methods for mutation analysis }\end{array}$ & $\begin{array}{l}\text { Myriad, ER, HSC, } \\
\text { U Penn }\end{array}$ \\
\hline 1 & DNA sequences within BRCA2 & $\begin{array}{l}\text { Duke University } \\
\text { and CRC }\end{array}$ \\
\hline 2 & $\begin{array}{l}\text { Tools, methods, kits for specific } \\
\text { mutations }\end{array}$ & OncorMed \\
\hline \multicolumn{3}{|c|}{$\begin{array}{l}\text { UURF, University of Utah Research Foundation. } \\
\text { NIH, National Institutes of Health (USA). } \\
\text { CHUQ, Centre de Recherche du CHUL. } \\
\text { CI, Cancer Institute (Tokyo). } \\
\text { U Leiden, Rijksuniverseteit Te Leiden. } \\
\text { ER, Endo Recherche. } \\
\text { HSC, Hospital for Sick Children. } \\
\text { U Penn, University of Pennsylvania. } \\
\text { CRC, Cancer Research Campaign Technology Ltd. }\end{array}$} \\
\hline
\end{tabular}


but these methods are not critical to BRCAl testing (data not shown).

There are at least five patents that claim methods, sequences, and/or tools related to genetic tests for $B R C A 2$, and these have been assigned to at least three unique assignee groups. The earliest patent was assigned to Myriad and several coassignees and has resulted in multiple divisional patents. Additional patents were assigned to Duke University (Duke) (with the Cancer Research Campaign Technology Ltd. as a coassignee) and OncorMed that relate to mutations not specifically claimed by the Myriad patents.

Myriad's BRACAnalysis ${ }^{\circledR}$ is a test for mutations in both BRCA1 and BRCA2. Physicians must send blood to Myriad Diagnostic Laboratories for analysis. Three types of analyses are offered: (1) a comprehensive sequencing and rearrangement analysis, (2) a single site (mutation specific) analysis for a mutation already identified in a family member, and (3) a multisite analysis of the three mutations most common in people of Ashkenazi Jewish ancestry. ${ }^{39}$ In 2008, the costs associated with each of these tests were $\$ 3120, \$ 385$, and $\$ 460$, respectively (unpublished data). Results are made available 4 weeks after the testing begins. ${ }^{40}$

The BRCAl patents issued to the Myriad team and the $B R C A 1$ patents issued to OncorMed protect strikingly similar technologies; both groups claimed BRCA1 sequences and methods for screening for breast cancer susceptibility mutations. OncorMed and Myriad both filed suit against each other in the late 1990s. ${ }^{41}$ In May of 1998, this dispute was settled out of court, as Myriad purchased exclusive rights to OncorMed's current and pending patents and testing services, ${ }^{42}$ including OncorMed's licenses for the University of California's BRCA1 patents and the $B R C A 2$ patent owned by Duke ${ }^{4,44}$ giving Myriad exclusive rights to conduct $B R C A 1$ and $B R C A 2$ testing. Myriad also has obtained exclusive licenses from UURF for rights related to $B R C A 1$ and $B R C A 2$, and with the Trustees of the University of Pennsylvania, the Hospital for Sick Children, and Endorecherch, Inc. for rights related to $B R C A 2,{ }^{45}$ providing Myriad with all patent rights necessary for conducting $B R C A 1$ and $B R C A 2$ testing.

\section{DISCUSSION}

In this analysis of patent activity related to four available genetic tests, we have not found evidence that the fragmented ownership of patent rights has inhibited the development or commercialization of these tests (Table 5). In each case, all patent rights critical for performing the tests were successfully licensed to the current provider(s) (i.e., no products lacked critical tests), through either exclusive or nonexclusive agreements. However, this does not imply that tests are uniformly accessible, in terms of costs. In these case studies, tests of all known major genes/mutations were patented, whereas the rights to test extremely rare mutations or sequence genes that rarely harbor disease-associated mutations (i.e., accounting less than $\sim 0.05 \%$ of mutation carriers) were less likely to be patented and were often not included in testing services (LQTS, CF, MODY).

The claims analyzed in these case studies were constructed in several ways. In cases of allelic heterogeneity (i.e., many susceptibility mutations within the same gene), such as BRCA and MODY, some patents claim methods, sequences, and/or tools for mutational analysis, protecting the rights to detect any and all mutations within the sequences specified in the patent. The sequences claimed in these patents often include wild-type and/or mutant DNA sequence(s). Allelic heterogeneity can also be captured by crafting claims that are tools and/or methods for testing specific mutations (e.g., CF, LQTS).

Broad mutational analysis claims theoretically eliminate the need for individual claims related to testing specific mutations, assuming these mutations can be detecting using the patented mutational analysis technology. However, even if a broad patent has been issued, patents related to specific mutations can still be issued if the specific patents enhance the prior testing technology a new and nonobvious way. The owner of the broad patent can still practice the patented technology, provided the owner is not using any technologies claimed in the subsequent patents. However, as more specific patents are issued, the likelihood of an anticommons scenario may increase.

The cases examined here are characterized by modest amounts of locus heterogeneity (i.e., mutations in multiple genes predispose to the same disease), where each patented test applies to a sizable portion of the testable population. In cases of more extreme locus heterogeneity (i.e., rare mutations in many genes), such as nonsyndromic, autosomal-recessive deafness (DFNB), ${ }^{46}$ very few individual genetic tests are likely to be patented due to lack of utility for each individual test. DFNB was not considered an eligible case study for this study, because only one of the $>20$ DFNB genes was the subject of a patent. However, a pending US patent claims microarray-based methods for diagnosing pediatric hearing loss by screening for mutations in nine genes associated with hearing loss (Application no. 20050112598). These types of patents protect methods and tools for combining many tests of low individual utility into a single, potentially useful technology.

In contrast to the rare, high-risk genetic variants examined in this work, variants identified using GWA methodology are likely to be common polymorphisms ( $\geq 1 \%$ minor allele frequency) with modest effects on disease risk (risk ratios $<2.0$ ). Because testing for these variants has little clinical utility individually, it is not clear if patenting such tests will be worth-

Table 5 Summary of case studies

\begin{tabular}{lcccccc}
\hline Case study & Patents & ${\text { Assignee } \text { groups }^{a}}$ & Test providers & (Sub-)licenses granted to test providers & Litigation & Patent rights unified \\
\hline CF & 8 & 3 & $>60$ & Nonexclusive & No & Yes \\
MODY & 3 & 2 & 2 & Unclear & & No \\
LQTS & 17 & 3 & 1 & Exclusive & Yes & Yes \\
BRCA & 22 & 9 & 1 & Exclusive & Yes & Yes \\
\hline
\end{tabular}

${ }^{a}$ Multiple assignees can be listed on a patent. One party can belong to multiple assignee groups.

${ }^{b}$ There are two providers of MODY testing in the US, Athena and Ambry. Athena has secured a license from the owner of the patent rights (Correlagen and General Hospital Corp.). We were unable to determine how Ambry has obtained the rights to conduct MODY testing. 
while, given the costs associated with securing patent rights in the United States and elsewhere. However, a preliminary search of the USPTOs database of patent applications (i.e., pending patents) indicates that several findings from recent GWA studies (reviewed $i^{5}$ ) are the subjects of patent applications, including genetic markers for breast cancer (Application No. 20070166738), coronary heart disease (Application No. 20070015170), and diabetes (Application Nos. 20060286588 and 20060040293). Because patent applications are not posted on the USPTO website until 18 months after filing, the most recent patent applications on GWA findings are not yet available, making it difficult to accurately assess the extent to which patent applications on current developments in GWA studies are being filed. Patents on GWA discoveries could provide future opportunities to observe and study the assembly of patent rights.

In the future, should a sufficiently problematic anticommons arise around genetic tests for a specific disease, several tools are available to address the problem. Compulsory licensing is one such option, whereby a government can require a patent holder to license its patent rights to other public or private parties. Although there is no general compulsory licensing provision in US law, the US government can intervene in any of three ways: (1) by authorizing the use of a patent by or on behalf of the federal government (28 U.S.C. $§ 1498$ ); (2) by exercising its automatic license under the provisions of the Bayh Dole Act ${ }^{47}$ to patents arising from federal funding (35 U.S.C. $§ 202(c)^{4}$ ); and/or (3) by exercising "march-in rights" under the Bayh Dole Act (to grant licenses to federally funded patented technologies to private parties in the case where the patent owner has failed to adequately supply the market with products or services embodying the inventions, especially in cases where there is a compelling, unmet health or safety need that the invention could help ameliorate) (35 U.S.C. $§ 203) .{ }^{48}$ These options could increase access to essential patents in very specific situations, and reduce barriers associated with exclusive licensing. A patent pool is another potential solution to the anticommons problem, whereby two or more patent owners agree to license one or more of their patents to each other, as a package, or to third parties willing to pay licensing fees. Patent pools can serve to avoid royalty stacking and reduce the transaction costs associated with licensing patent from multiple owners. ${ }^{49}$ A third option is a clearinghouse, an entity that matches licensees with licensors and oversees licensing agreements. This strategy also reduces transaction costs, potentially increasing access to patented technologies. ${ }^{50}$

Although this work focuses on US patents, it is important to note that the mechanisms by which an anticommons can be addressed vary by country. For example, the international Agreement on Trade-Related Aspects of Intellectual Property Rights that emerged from the Uruguay Round of the General Agreement on Tariffs and Trade in 1993, which sets standards of intellectual property regulation for members of the World Trade Organization, grants members states the right to disregard patents or grant compulsory licenses in situations where public health is threatened. ${ }^{51}$ Several European countries have responded by enacting public health-related compulsory license clauses, although the US has not yet enacted such a clause. ${ }^{52}$

The NIH has suggested several "best practices" for licensing NIH-funded genetic inventions that would theoretically reduce the likelihood of an anticommons arising in the field of genome diagnostics (69 FR 67747). For example, the NIH discourages patenting of inventions that require little addition research and development for commercial applications (69 FR 67747). It has been argued that diagnostic gene patents fall under this descrip- tion, being unnecessary for test development or the stimulation of downstream development of therapeutics. ${ }^{2}$ The NIH also recommends the use of nonexclusive licensing agreements whenever possible, to maximize access to patented technologies (69 FR 67747). The University of Michigan Technology Transfer office, which licenses CF-related patent rights nonexclusively, takes a similar stance and argues that nonexclusive licensing encourages competition among diagnostic laboratories, resulting in widely available and affordable CF testing. ${ }^{13}$ Despite this argument, a 2002 report from the Organization for Economic Co-operation and Development notes that exclusivity may be necessary to make testing economically feasible, depending on the size of the market, disease prevalence, and test complexity. ${ }^{53}$ It has also been suggested that monopolies in genetic testing result in a lack of incentive for test improvement. ${ }^{54}$ For example, recent report suggested that Myriad's sequencing methods were unable to detect many large deletions and duplications in BRCA1 and BRCA2.55 However, subsequent to this report, Myriad has made available the BRACAnalysis ${ }^{\circledR}$ Large Rearrangement Test, which reportedly detects all large rearrangement mutations in BRCA1 and BRCA2.

To our knowledge, this is the first study to describe the assignment and licensing of patents related to genetic tests and to examine the empirical evidence that fragmented ownership of patent rights can inhibit the development of genetic tests. A diverse set of publically-available resources were used in this case study analysis (e.g., SEC disclosure documents, press releases, patents, websites), highlighting the feasibility of this type of research despite the general inaccessibility of some primary data sources (e.g., license agreements). This work is timely given the recent surge in discoveries of genetic variants that influence complex disease and the potential for these variants to be used in panels of genetic tests that help predict or diagnose disease. ${ }^{6}$ The potential utility of this genetic information is further enhanced by the passage of the Genetic Information and Nondiscrimination Act of 2007-2008 (H.R. 493), which prohibits employers and insurers from discriminating on the basis of genetic information.

This analysis is limited by incomplete information on the details of license agreements and agreements among coassignees because such information is not always publically available. We lacked information on license exclusivity (for MODY), specific patents or claims transferred between parties, licensing fees, and field of use restrictions. In addition, we did not speculate as to what degree specific patents may or may not successfully prevent other diagnostics companies from conducting genetic tests. It is possible that alternative methods of testing could be developed (i.e., antibodies, biomarkers of downstream abnormalities), but the nature of the claims in many gene diagnostic patents, especially those claiming genetic sequences, may make them difficult to "invent around." 56 At the same time, however, patents are only presumptively valid when issued by the USPTO and can be invalidated as part of a defense to a patent infringement lawsuit, or as part of a declaratory judgment action brought in federal court by a private party that can show it has been directly threatened with legal action by a patent holder. Further, a member of the public can request that the USPTO reexamine an issued patent, which could lead to post issuance rejection and cancellation of the patent, or a reissuance with modified claims. The USPTO is not obligated to undertake a reexamination upon such request, but it does have to respond to the petitioner as to whether it will undertake the reexamination or not. A 2005 study suggests that a sizeable portion of gene patents may fall short of the statutory requirements for patentability, potentially making gene patents more vulnerable 
than other patents to invalidation (in court), cancelation, or modification (in reexamination proceedings). 57

We did not identify any eligible case studies that were not associated with a test that is currently available. This is a key limitation, because we were only able to observe "inhibition" through two sources: (1) available, yet incomplete, diagnostic tools, including instances in which existing services do not incorporate new, patented tests, and (2) legal hurdles (e.g., litigation) documented in publicly available sources. However, the litigation observed in these case studies was not a direct result of the anticommons problem. In the case of BRCA, litigation was likely a consequence of the USPTOs decision to issue very similar patents to Myriad and OncorMed. In the case of LQTS, the rightful owner of all relevant patent rights took action against a company that was clearly infringing. Therefore, we cannot conclude that we observed any "inhibition" due to fragmented ownership. It has also been argued that exclusive licensing and genetic testing monopolies may lead to higher costs. ${ }^{1,2} \mathrm{We}$ did not attempt to assess the relationship between market exclusivity and cost, as cost depends on many factors not measured in this work, such as test complexity and disease prevalence.

In conclusion, we have not found evidence that fragmented ownership of patent rights has inhibited the development or commercialization of genetic tests. All of the currently available genetic tests examined in this analysis are covered by multiple patents, but in each case, all patents were unified via licensing, without intervention from government (e.g., compulsory licensing) or groups of patent holders (e.g., patent pool). Genetic tests based on GWA discoveries may offer new challenges to companies interested in genetic testing, as the number of known disease susceptibility variants increases, but there are several available mechanisms for preventing and/or eliminating an anticommons in the field of genomic diagnostics.

\section{ACKNOWLEDGEMENTS}

This work was supported by National Cancer Institute training grant R25-CA94880.

We thank Sean O'Connor for reviewing this paper and providing advice related to this work. We also thank Chris Holman for his valuable contributions to this project.

\section{REFERENCES}

1. Andrews LB, Paradise J. Gene patents: the need for bioethics scrutiny and legal change. Yale J Health Policy Law Ethics 2005;5:403-412.

2. Merz JF. Disease gene patents: overcoming unethical constraints on clinical laboratory medicine. Clin Chem 1999;45:324-330.

3. Heller MA, Eisenberg RS. Can patents deter innovation? The anticommons in biomedical research. Science 1998;280:698-701.

4. Barton JH. Emerging patent issues in genomic diagnostics. Nat Biotechnol 2006;24:939-941

5. Topol EJ, Murray SS, Frazer KA. The genomics gold rush. JAMA 2007;298: $218-221$

6. McCarthy MI, Abecasis GR, Cardon LR, et al. Genome-wide association studies for complex traits: consensus, uncertainty and challenges. Nat Rev Genet 2008:9:356-369.

7. National Institutes of Health. Genetic testing for cystic fibrosis. National Institutes of Health Consensus Development Conference Statement on genetic testing for cystic fibrosis. Arch Intern Med 1999;159:1529-1539.

8. Watson MS, Cutting GR, Desnick RJ, et al. Cystic fibrosis population carrier screening: 2004 revision of American College of Medical Genetics mutation panel. Genet Med 2004;6:387-391.

9. Committee on Genetics, American College of Obstetricians and Gynecologists. ACOG Committee Opinion. Number 325, December 2005. Update on carrier screening for cystic fibrosis. Obstet Gynecol. 2005;106:1465-1468.

10. Medical Genetics Laboratories at Baylor College of Medicine. Available at: http://www.bcm.edu/geneticlabs/cptcodes.html. Accessed December 1, 2007.

11. Emory Genetics Laboratory. Available at: http://genetics.web.emory.edu/egl/ testmenu_parent.php. Accessed December 1, 2007.
12. Luminex Corporation. Available at: http://www.luminexcorp.com/products/ assays/cftr_ivd.html. Accessed December 1, 2007.

13. University of Michigan Tech Transfer. Available at: http://www.techtransfer. umich.edu/news_events/success_stories/story_19.php. Accessed December 7, 2007.

14. Reuters. Luminex licenses cystic fibrosis gene patent from John Hopkins. Available at: http://www.reuters.com/article/inPlayBriefing/ idUSIN20070424090442LMNX20070424. Accessed August 20, 2008.

15. Froguel P, Velho G. Molecular genetics of maturity-onset diabetes of the young. Trends Endocrinol Metab 1999;10:142-146.

16. Fajans SS, Bell GI, Polonsky KS. Molecular mechanisms and clinical pathophysiology of maturity-onset diabetes of the young. N Engl J Med 2001;345: 971-980.

17. Velho G, Robert JJ. Maturity-onset diabetes of the young (MODY): genetic and clinical characteristics. Horm Res. 2002;57(suppl 1):29-33.

18. Shepherd M, Ellis I, Ahmad AM, et al. Predictive genetic testing in maturityonset diabetes of the young (MODY). Diabet Med 2001;18:417-421.

19. University of Chicago Office of Technology and Intellectual Property. Available at: http://tech.uchicago.edu/about/history.shtml. Accessed November 11, 2007.

20. Malecki MT, Jhala US, Antonellis A, et al. Mutations in NEUROD1 are associated with the development of type 2 diabetes mellitus. Nat Genet 1999;23:323-328

21. IntegraGen, 2004. Available at: http://www.integragen.com/fileadmin/media/ Press/2004-11-08_EN.pdf. Accessed November 11, 2007.

22. Correlagen Inc. Available at: http://www.correlagen.com/fields/endocrinology/ brochures/pdfs/MODY.pdf. Accessed November 11, 2007.

23. Athena Diagnostics. Available at: http://www.athenadiagnostics.com/content/ test-catalog/find-test/service-detail/q/id/274. Accessed August 20, 2008.

24. Ambry Genetics. Available at: http://www.ambrygen.com/ts/ts_mody.aspx. Accessed August 20, 2008.

25. Modell SM, Lehmann MH. The long QT syndrome family of cardiac ion channelopathies: a HuGE review. Genet Med 2006;8:143-155.

26. Napolitano C, Priori SG, Schwartz PJ, et al. Genetic testing in the long QT syndrome: development and validation of an efficient approach to genotyping in clinical practice. JAMA 2005;294:2975-2980.

27. Priori SG, Schwartz PJ, Napolitano C, et al. Risk stratification in the long-QT syndrome. N Engl J Med 2003;348:1866-1874.

28. Schwartz PJ, Priori SG, Spazzolini C, et al. Genotype-phenotype correlation in the long-QT syndrome: gene-specific triggers for life-threatening arrhythmias. Circulation 2001;103:89-95

29. PGxHealth. Familion frequently asked questions. Available at: http://www pgxhealth.com/genetictests/familion/physicians/faq.cfm. Accessed September 6,2007

30. PGxHealth. Payment authorization form. Available at: http://www pgxhealth.com/genetictests/familion/pdf/FAMILION\%20Payment $\%$ 20Authorization\%20Form_V07PA0130\%20Branded.pdf. Accessed September 6,2007

31. PGxHealth. The familion test technical specifications. March 2007. Available at: http://www.pgxhealth.com/genetictests/familion/pdf/FAMILION\% 20Test $\% 20$ Tech\%20Sheet $\% 2007$ TS0305.pdf. Accessed September 6, 2007.

32. Genaissance Pharmaceuticals. Form 10-K: U.S. Securities and Exchange Commission. Genaissance Pharmaceuticals, March 15, 2005. Available at: http://www.secinfo.com. Accessed February 19, 2009.

33. DNA Sciences, 2000. Available at: http://findarticles.com/p/articles/mi pwwi/is_200011/ai_mark09019680. Accessed December 10, 2007.

34. Holman CM. The impact of human gene patents on innovation and access: a survey of human gene patent litigation. UMKC Law Rev. 2007;76:295-361.

35. Statement by Dr. Marc Grodman at the House Judiciary Subcommittee on Courts, the Internet and Intellectual Property's hearing on "Stifling or Stimulating-The Role of Gene Patents in Research and Genetic Testing." October 30, 2007.

36. Nelson HD, Huffman LH, Fu R, Harris EL. Genetic risk assessment and BRCA mutation testing for breast and ovarian cancer susceptibility: systematic evidence review for the U.S. Preventive Services Task Force. Ann Intern Med 2005; $143: 362-379$

37. American Society of Clinical Oncology. Statement of the American Society of Clinical Oncology: genetic testing for cancer susceptibility. J Clin Oncol 1996;14:1730-1736; discussion 1737-1740.

38. American College of Medical Genetics Professional Practice and Guidelines Committee. Genetics susceptibility to breast and ovarian cancer: assessment, counseling, and testing guidelines executive summary. American College of Medical Genetics Professional Practice and Guidelines Committee, 1999. Available at: http://www.health.state.ny.us/nysdoh/ cancer/obcancer/contents.htm. Accessed February 19, 2009.

39. Myriad Genetics Inc. Available at: http://www.myriadtests.com/provider/doc/ BRACAnalysis-Technical-Specifications.pdf. Accessed November 11, 2007.

40. Myriad Genetics Inc. Available at: http://www.myriadtests.com/provider/ testingprocess.htm. Accessed December 1, 2007.

41. Marshall E. The battle over BRCA1 goes to court; BRCA2 may be next. Science 1997;278:1874

42. Oncormed Inc. Form 10-Q: U.S. Securities and Exchange Commission. Oncormed Inc., August 14, 1998. Available at: http://www.secinfo.com. Accessed February 19, 2009. 
43. Oncormed Inc. 10-K405: U.S. Securities and Exchange Commission. Oncormed Inc., March 31, 1998. Available at: http://www.secinfo.com. Accessed February 19, 2009.

44. Parthasarathy S. Building genetic medicine. Cambridge, Massachusetts: The MIT Press, 2007.

45. Myriad Genetics Inc. Form 10-K: U.S. Securities and Exchange Commission. Myriad Genetics Inc., August 29, 2007.

46. Petersen MB, Willems PJ. Non-syndromic, autosomal-recessive deafness. Clin Genet 2006;69:371-392.

47. Pub. L. No. 96-517, 94 Stat. 3015, 3019-27 (1980) (codified at 35 U.S.C. $\S \S$ 200-211).

48. O'Connor SM. Enabling research or unfair competition? De jure and de facto research use exceptions in major technology countries. In: Takenaka T, Moufang R, editors. Patent law: a handbook of contemporary research. Cheltenham, UK: Edward Elgar Publishing Limited, 2008.

49. Verbeure B, van Zimmeren E, Matthijs G, Van Overwalle G. Patent pools and diagnostic testing. Trends Biotechnol 2006;24:115-120.

50. van Zimmeren E, Verbeure B, Matthijs G, Van Overwalle G. A clearing house for diagnostic testing: the solution to ensure access to and use of patented genetic inventions? Bull World Health Organ 2006;84:352-359.

51. Andrews LB. Genes and patent policy: rethinking intellectual property rights. Nat Rev Genet 2002;3:803-808

52. Van Overwalle G, van Zimmeren E, Verbeure B, Matthijs G. Models for facilitating access to patents on genetic inventions. Nat Rev Genet 2006;7:143-148.

53. Organisation for Economic Co-operation and Development. Genetic inventions, intellectual property rights, and licensing practices. Paris, France: Organisation for Economic Co-operation and Development, 2002.

54. Cho MK, Illangasekare S, Weaver MA, Leonard DG, Merz JF. Effects of patents and licenses on the provision of clinical genetic testing services. J Mol Diagn 2003;5:3-8.

55. Walsh T, Casadei S, Coats KH, et al. Spectrum of mutations in BRCA1, BRCA2, CHEK2, and TP53 in families at high risk of breast cancer. JAMA 2006;295:1379-1388.

56. Nuffield Council on Bioethics. The ethics of patenting DNA. London: Nuffield Council on Bioethics, 2002.

57. Paradise J, Andrews L, Holbrook T. Intellectual property. Patents on human genes: an analysis of scope and claims. Science 2005;307:1566-1567. 